九州大学学術情報リポジトリ

Kyushu University Institutional Repository

\title{
Behavior of Cold Water Mass Due to Water Surface Cooling in a Closed Water Body
}

Kakizaki, Shinnosuke

Graduate School of Bioresource and Bioenvironmental Sciences, Kyushu University

Hamagami, Kunihiko

Graduate School of Bioresource and Bioenvironmental Sciences, Kyushu University

Mori, Ken

Faculty of Agriculture, Kyushu University

Hirai, Yasumaru

Faculty of Agriculture, Kyushu University

https://doi.org/10.5109/9250

出版情報: 九州大学大学院農学研究院紀要. 51 (2)，pp.331-336，2006-10-27. Faculty of Agriculture, Kyushu University

バージョン :

権利関係 : 


\title{
Behavior of Cold Water Mass Due to Water Surface Cooling in a Closed Water Body
}

\author{
Shinnosuke KAKIZAKI ${ }^{1}$, Kunihiko HAMAGAMI ${ }^{1}$, Ken MORI* \\ and Yasumaru HIRAI
}

\author{
Laboratory of Bioproduction and environmental information Sciences, Division of Bioproduction and Environment \\ Information Sciences, Department of Bioproduction and Environmental Science, \\ Factory of Agriculture, Kyushu University, Fukuoka 812-8581, Japan \\ (Received June 30, 2006 and accepted July 24, 2006)
}

\begin{abstract}
In some closed water bodies with little inflow and outflow, a flow is gentle and its water quality gets worse by developing stratification. And its main dynamics of flow are circulation flow based on wind action on a water surface (mechanical disturbance) and a thermal convective flow by solar radiation. (thermal disturbance)

In the present research, we focused on a closed water body where thermal turbulence was outstanding. Hydraulic experiments were conducted to investigate the behavior of the cold water mass formed around a water surface when the water surface was cooled naturally. And the difference of the behavior was investigated under coverage and no-coverage plants on a water surface.

Results indicated that turbulence intensity of the cold water mass and the time scale of convection were influenced by both the Rayleigh number and coverage. The falling cycle of cold water mass was influenced by only the Rayleigh number. The falling cycle of cold water mass and development of convective a flow were also observed by the wavelet transform in the change of water temperature.
\end{abstract}

\section{INTRODUCTION}

In a closed water body, density stratification is formed by physical, biological, and biochemistrical factors. For example, there are water temperature stratification due to solar radiation during daytime and radiation cooling during night, water quality stratification due to liquation of the nutritive salts from bottom mud, and DO stratification secondarily produced by plankton etc. For conservation or improvement of water quality in a closed water body, it is important to use circulation flows by a wind induced flow (mechanical disturbance) and a thermal a convective flow (thermal disturbance). And it is also important to apply the function of water quality purification by aquatic plants, because aquatic plants have the capability to absorb nutritive salts that leads to eutrophication (Masujima, et al., 2001).

In the present study, we focused on the closed water bodies with floating aquatic plants where especially thermal turbulence was outstanding. Hydraulic characteristics at the initial stage of formation of a thermal convective flow due to water surface cooling were measured around a water surface.

\section{MATERIAL AND METHODS}

The experiment for the behavior of cold water masses Experimental equipment

Experimental equipment is shown in Fig. 1. Area of

\footnotetext{
1 Laboratory of Bioproduction and Environmental Information Sciences, Division of Bioproduction and Environment Sciences, Department of Bioproduction Environmental Sciences, Graduate School of Bioresource and Bioenvironmental Sciences, Kyushu University

* Corresponding author (E-mail: moriken@bpes.Kyushu-u.ac.jp)
}

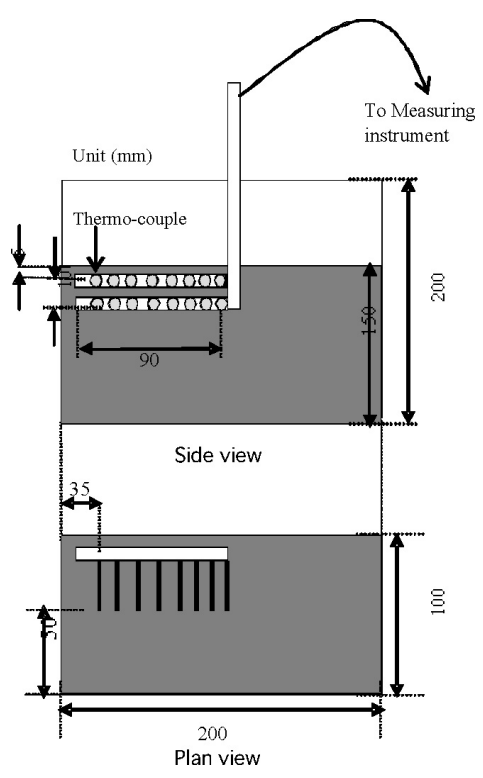

Fig. 1. Experimental equipment.

water surface was $100 \mathrm{~mm} \times 200 \mathrm{~mm}$ and the depth was $200 \mathrm{~mm}$. It was made from an acrylics board of $5 \mathrm{~mm}$ thickness. The tank was covered with styrene foam of $20 \mathrm{~mm}$ thickness at the bottom and sides to make heat transfer minimum.

Thermocouples were set 16 points. These were set at points of $5 \mathrm{~mm}$ and $15 \mathrm{~mm}$ under a water surface, and set in a horizontal direction at intervals of $10 \mathrm{~mm}$. We named upper sensors $\mathrm{H}$ and lower ones $\mathrm{L}$, and gave the number from the left side. We used the Thermodac $\mathrm{F}$ (ETO DENKI CO., 5030A) and Ondotori (TANDA, TR-71U) were used for our measurement. 


\section{Experimental method}

The experiment was conducted indoors, and the conditions of air were not controlled. The experimental fluid was tap water. Surface cooling was conducted under the temperature difference between air and hot water. Heat insulation state was maintained and water temperature distribution was uniformed, and then water surface cooling started. Water temperature was measured for 20 minutes at $2.5 \mathrm{~Hz}$ of sampling frequency. Variation of water temperature was measured as voltage value variation.

In addition, in this experiment, coverage of the water surface was changed with $0 \%, 20 \%, 40 \%$, and $60 \%$. The styrene foam board of $5 \mathrm{~mm}$ thickness was used to simulate floating aquatic plants.

\section{Experimental condition}

The Rayleigh number was introduced as one of the experimental conditions, which were defined as

$$
R_{a}=\frac{a g \Delta T h^{3}}{\kappa v}=\frac{a g q h^{4}}{\rho C_{p} K^{2} v}
$$

where $\boldsymbol{a}$ is coefficient of thermal expansion $\left(1 /{ }^{\circ} \mathrm{C}\right) ; \Delta T$, temperature difference between air and water $\left({ }^{\circ} \mathrm{C}\right) ; h$, depth of water $(\mathrm{cm}) ; \kappa$, rate of heat conduction $\left(\mathrm{cm}^{2} / \mathrm{s}\right)$; $v$, coefficient of kinematic viscosity $\left(\mathrm{cm}^{2} / \mathrm{s}\right) ; q$, heat flux $\left(\mathrm{cal} / \mathrm{cm}^{2} \square \mathrm{s}\right) ; \rho$, water density $\left(\mathrm{g} / \mathrm{cm}^{3}\right) ; C_{p}$, specific heat $\left(\mathrm{cal} / \mathrm{g} \square{ }^{\circ} \mathrm{C}\right) ; g$, gravitational acceleration $\left(\mathrm{cm} / \mathrm{s}^{2}\right)$.

The experimental conditions are shown in Table 1. In calculation of the Rayleigh number, $a=2.5 \times 10^{-4}, g=$ $980, \kappa=1.4 \times 10^{-4}$ and $\boldsymbol{v}=0.01$ were used.

\section{RESULTS AND DISCUSSIONS}

Time variation of water temperature and the number of falling cold water masses

Figure 2 shows time variation of the water temperature in case $1-1$ and case4-1. In this figure, starting points of voltage were shifted down $0.05 \mathrm{mV}$ successively in order to distinguish the change in water temperature at each measurement point. Moreover, the number of falling cold water masses was counted within 20 minutes by the upper sensor. The result is shown in Table 2 .

The water temperature decreased rapidly around the water surface at the initial stage of cooling. Therefore, a density difference arose and a multitude of cold water masses appeared in the whole water surface. In this research, rapid temperature variations generated intermittently were defined as falling of cold water mass. The water temperature decreased gradually on the whole. When the coverage was high, amount of decrease was small. When the Rayleigh number was large, the number of falling cold water masses increased. Comparing upper sensors with lower sensors, upper ones reacted sharply and then lower ones reacted weakly with some time lag. The number of falling cold water masses decreased greatly at the covered portion and in the vicinity of covered portion. It was thought that generating of cold water masses and the scale of thermal convective flow were influenced greatly by coverage.

\section{Turbulence intensity}

Turbulence intensity of temperature change was defined as

$$
T_{r m s}=\sqrt{\frac{\sum T^{2}}{n}}
$$

where $T$ is the change of water temperature; $n$, the number of data. Figure 3 shows turbulence intensity in case 1 and case 4 . When the Rayleigh number was large, the turbulence intensity became large, too, and also became large at the center of the tank. For depth of water, turbulence intensity was large around the water surface, and this was the reason why density instability tends to become large. For the coverage, turbulence intensity decreased at the covered portion but increased rapidly around the covered portion.

\section{Characteristics of cold water masses}

In order to investigate the characteristics of cold water masses, the data was processed by power spec-

\begin{tabular}{|c|c|c|c|c|c|}
\hline & coverage (\%) & $\begin{array}{c}\text { water temperature } \\
\left({ }^{\circ} \mathrm{C}\right)\end{array}$ & $\begin{array}{l}\text { air temperature } \\
\left({ }^{\circ} \mathrm{C}\right)\end{array}$ & $\begin{array}{l}\text { difference bitween air } \\
\text { temperature and water } \\
\text { temperature } \Delta T\left({ }^{\circ} \mathrm{C}\right)\end{array}$ & $\begin{array}{l}\text { Rayleigh } \\
\text { number }\end{array}$ \\
\hline case $1-1$ & 0 & 18.3 & 3.7 & 14.6 & $8.62 \mathrm{E}+09$ \\
\hline case1-2 & 0 & 15.1 & 3.4 & 11.7 & $6.91 \mathrm{E}+09$ \\
\hline case1-3 & 0 & 12.4 & 3.3 & 9.1 & $5.37 \mathrm{E}+09$ \\
\hline case $1-4$ & 0 & 9.1 & 3.3 & 5.8 & $3.43 \mathrm{E}+09$ \\
\hline case2-1 & 20 & 17.5 & 3.3 & 14.2 & $8.39 \mathrm{E}+09$ \\
\hline case2-2 & 20 & 14.7 & 3.0 & 11.7 & $6.91 \mathrm{E}+09$ \\
\hline case $2-3$ & 20 & 12.9 & 3.8 & 9.1 & $5.37 \mathrm{E}+09$ \\
\hline case $3-1$ & 40 & 18.2 & 2.9 & 15.3 & $9.04 \mathrm{E}+09$ \\
\hline case $3-2$ & 40 & 14.9 & 2.9 & 12.0 & $7.09 \mathrm{E}+09$ \\
\hline case $3-3$ & 40 & 12.9 & 4.2 & 8.7 & $5.14 \mathrm{E}+09$ \\
\hline case4-1 & 60 & 18.0 & 3.2 & 14.8 & $8.74 \mathrm{E}+09$ \\
\hline case4-2 & 60 & 14.8 & 2.9 & 11.9 & $7.03 \mathrm{E}+09$ \\
\hline case4-3 & 60 & 13.1 & 4.4 & 8.7 & $5.14 \mathrm{E}+09$ \\
\hline
\end{tabular}

Table 1. Experimental condition 


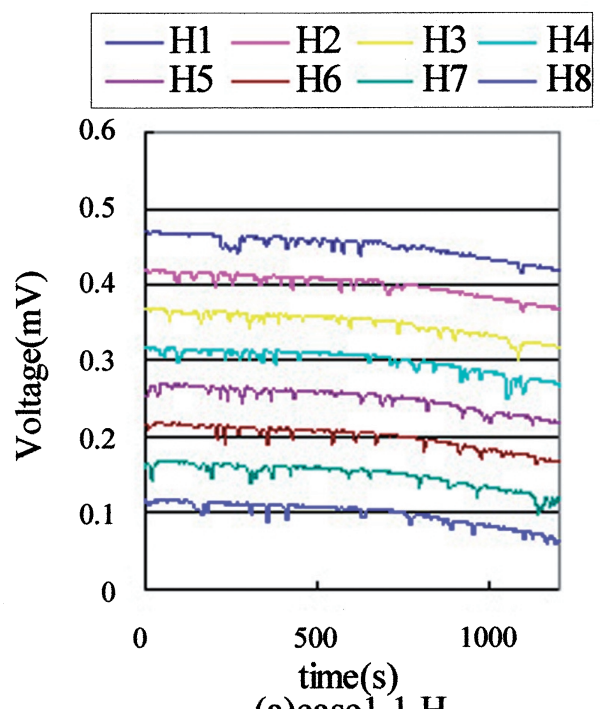

(a)case1-1-H

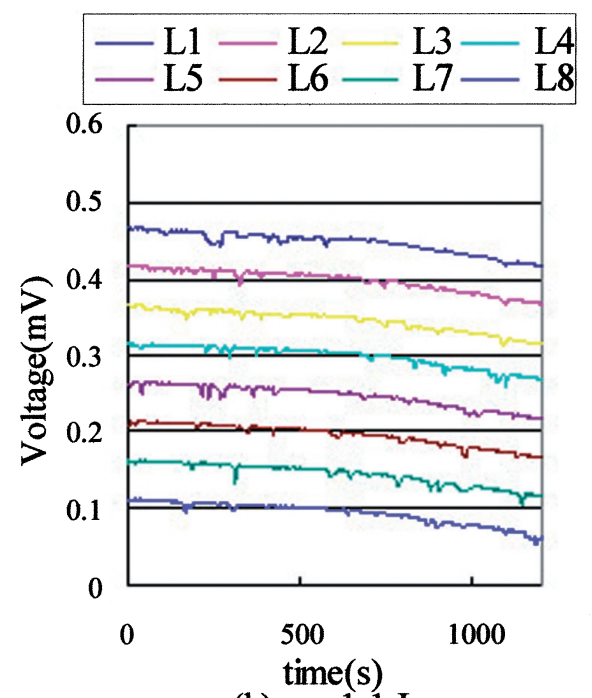

(b)case 1-1-L

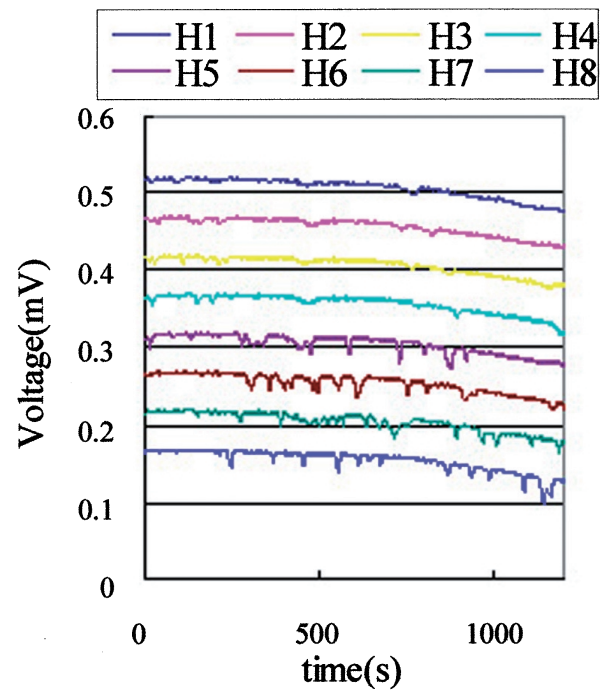

(c)case4-1-H

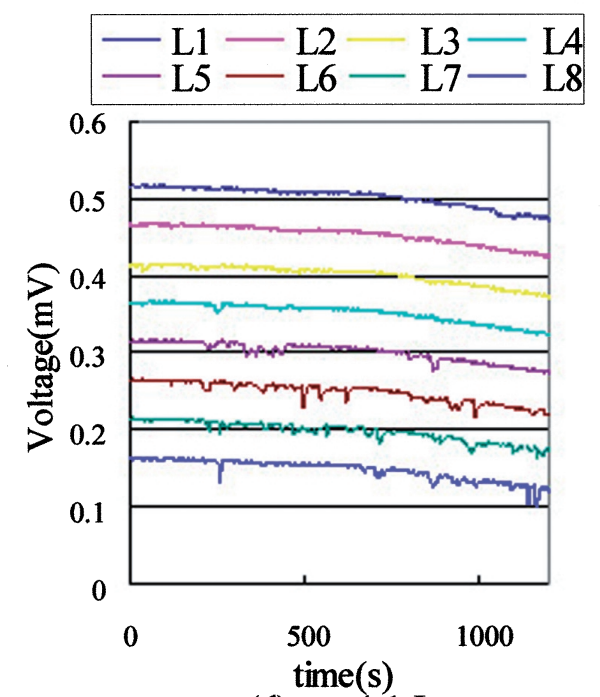

(d)case4-1-L

Fig. 2. Variation of water temperature.

Table 2. Number of falling cold water masses

\begin{tabular}{|c|c|c|c|c|c|c|c|c|c|c|c|c|}
\hline \multirow{2}{*}{$\begin{array}{l}\text { coverage } \\
(\%)\end{array}$} & \multirow{2}{*}{$\begin{array}{c}\text { difference of } \\
\text { temperature } \\
\left({ }^{\circ} \mathrm{C}\right)\end{array}$} & \multirow[t]{2}{*}{ case } & \multicolumn{9}{|c|}{$\begin{array}{l}\text { the number of sencor and } \\
\text { counted sedimentation }\end{array}$} & \multirow{2}{*}{$\begin{array}{l}\text { Rayleigh } \\
\text { number Ra }\end{array}$} \\
\hline & & & 1 & 2 & 3 & 4 & 5 & 6 & 7 & 8 & sum & \\
\hline \multirow{4}{*}{0} & 15 & case1-1-H & 30 & 27 & 34 & 37 & 33 & 31 & 31 & 27 & 250 & $8.62 \mathrm{E}+09$ \\
\hline & 12 & case1-2-H & 19 & 18 & 20 & 24 & 20 & 22 & 23 & 20 & 166 & $6.91 \mathrm{E}+09$ \\
\hline & 9 & case1-3-H & 15 & 16 & 17 & 16 & 14 & 18 & 19 & 20 & 135 & $5.37 \mathrm{E}+09$ \\
\hline & 6 & case $1-4-\mathrm{H}$ & 10 & 8 & 9 & 13 & 12 & 12 & 11 & 12 & 87 & $3.43 \mathrm{E}+09$ \\
\hline \multirow{3}{*}{20} & 15 & case2-1-H & 10 & 11 & 12 & 21 & 22 & 25 & 22 & 28 & 151 & $8.39 \mathrm{E}+09$ \\
\hline & 12 & case $2-2-\mathrm{H}$ & 15 & 15 & 17 & 19 & 18 & 22 & 23 & 27 & 156 & $6.91 \mathrm{E}+09$ \\
\hline & 9 & case $2-3-\mathrm{H}$ & 12 & 11 & 14 & 13 & 17 & 17 & 18 & 18 & 120 & $5.37 \mathrm{E}+09$ \\
\hline \multirow{3}{*}{40} & 15 & case $3-1-\mathrm{H}$ & 8 & 10 & 27 & 31 & 32 & 32 & 31 & 31 & 202 & $9.04 \mathrm{E}+09$ \\
\hline & 12 & case3-2-H & 7 & 5 & 11 & 14 & 15 & 16 & 22 & 19 & 109 & $7.09 \mathrm{E}+09$ \\
\hline & 9 & case $3-3-\mathrm{H}$ & 7 & 8 & 13 & 14 & 14 & 15 & 18 & 18 & 107 & $5.14 \mathrm{E}+09$ \\
\hline \multirow{3}{*}{60} & 15 & case4-1-H & 10 & 10 & 11 & 10 & 17 & 19 & 22 & 19 & 118 & $8.74 \mathrm{E}+09$ \\
\hline & 12 & case $4-2-\mathrm{H}$ & 6 & 7 & 8 & 8 & 11 & 15 & 13 & 15 & 83 & $7.03 \mathrm{E}+09$ \\
\hline & 9 & case $4-3-\mathrm{H}$ & 3 & 6 & 6 & 7 & 11 & 11 & 12 & 12 & 68 & $5.14 \mathrm{E}+09$ \\
\hline
\end{tabular}


trum analysis and wavelet analysis. Figure 4 shows the relation between the Rayleigh number $R_{a}$ and the generating cycle of cold water masses $T_{p}$. It is known that the following relation between $T_{p}$ and $R_{a}$, and Fig. 4 shows the relation below is satisfied.

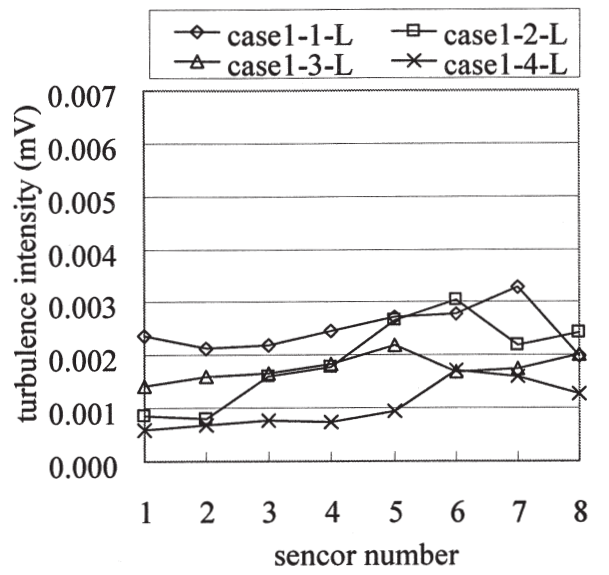

(a)case1-L

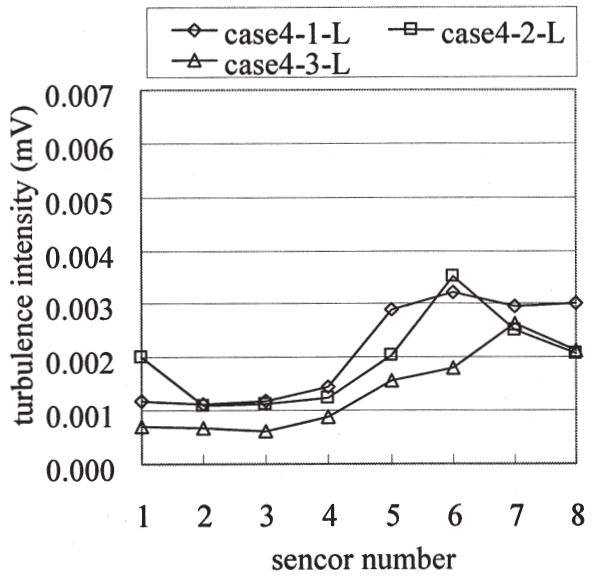

(c)case4-L

$$
T_{p} /\left(d^{2} / \mathbf{K}\right) \propto R_{a}^{-1 / 2}
$$

where $T_{p}$ is a generating cycle of cold water masses; $d$, water depth; к, Karman constant; $R_{a}$, Rayleigh number. Because the Rayleigh number was large around the

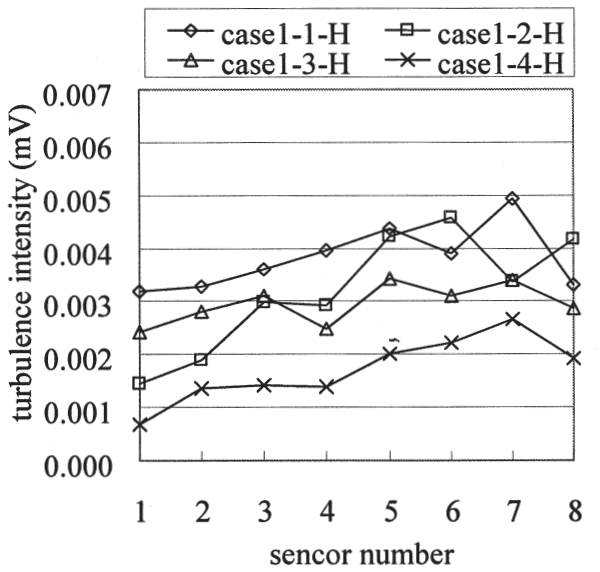

(b)case1-H

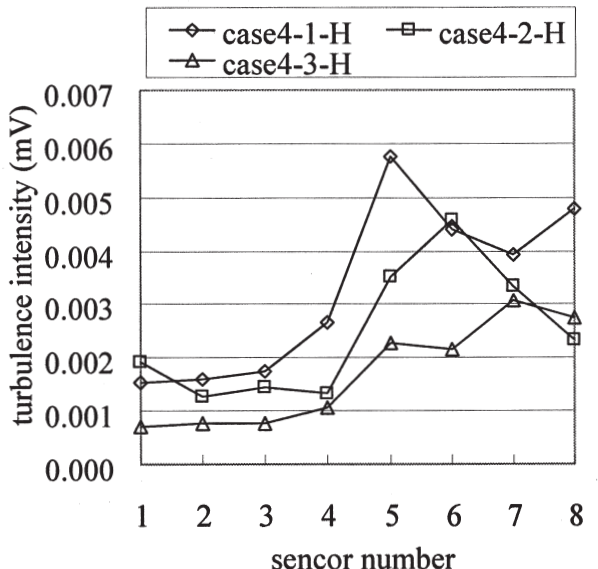

(d)case4-H

Fig. 3. Turbulence intensity.

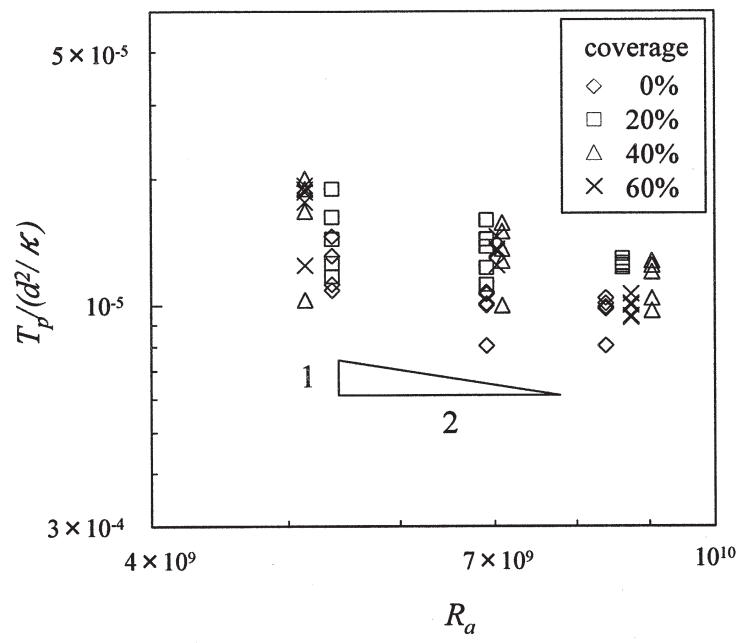

Fig. 4. Relation between the Rayleigh number $R_{a}$ and falling cycle of cold water mass $T_{p}$.

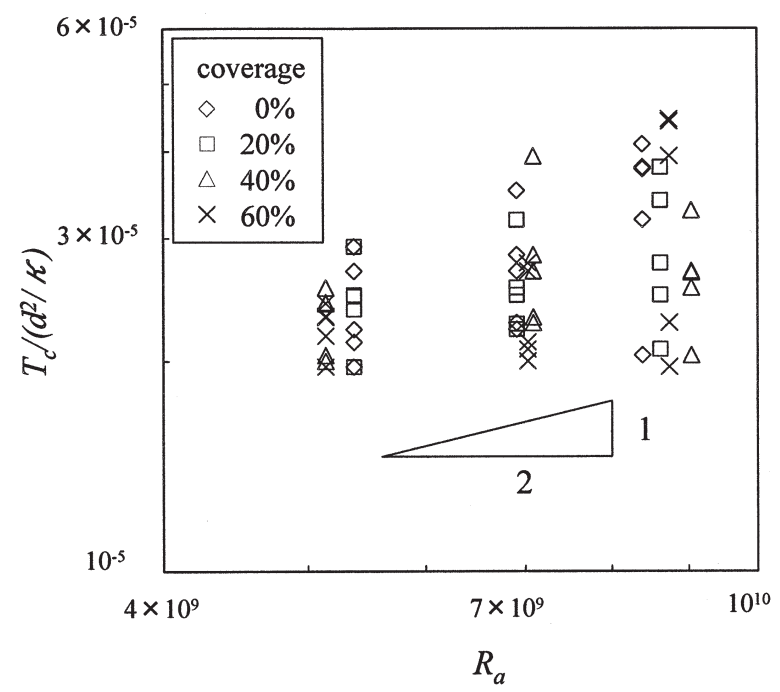

Fig. 5. Relation between the Rayleigh number $R_{a}$ and the time scale of convection $T_{c}$. 
water surface, density instability increased in a short time, so the generating cycle of cold water masses became short, too. It was not related with the amount of the coverage.

Furthermore, Fig. 5 shows the relation between the Rayleigh number $R_{a}$ and the time scale of a thermal convective flow $T_{c}$. The following relation between $T_{c}$ and $R_{a}$ was applied in the previous research (Eguchi et al., 2003). Figure 5 shows that this relationship is satisfied in this research.

$$
T_{c} /\left(d^{2} / \mathbf{K}\right) \propto R_{a}^{1 / 2}
$$

where $T_{c}$ is time scale of convective flow; $d$, water depth; $\mathrm{\kappa}$, Karman constant; $R_{a}$ is Rayleigh number. Time scale of a thermal convective flow became large when the Rayleigh number was large, because cold water masses were generated in a short cycle and the strong convec-
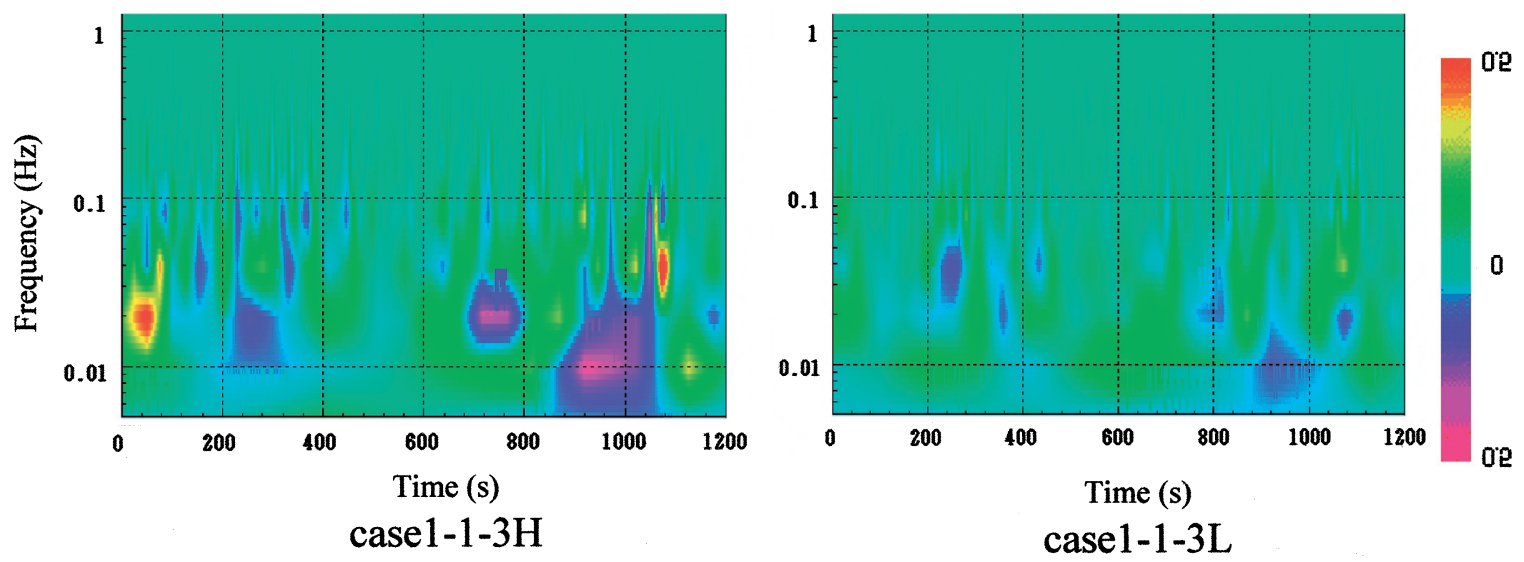

Fig. 6. Wavelet analysis in case1-1-3H and case1-1-3L.
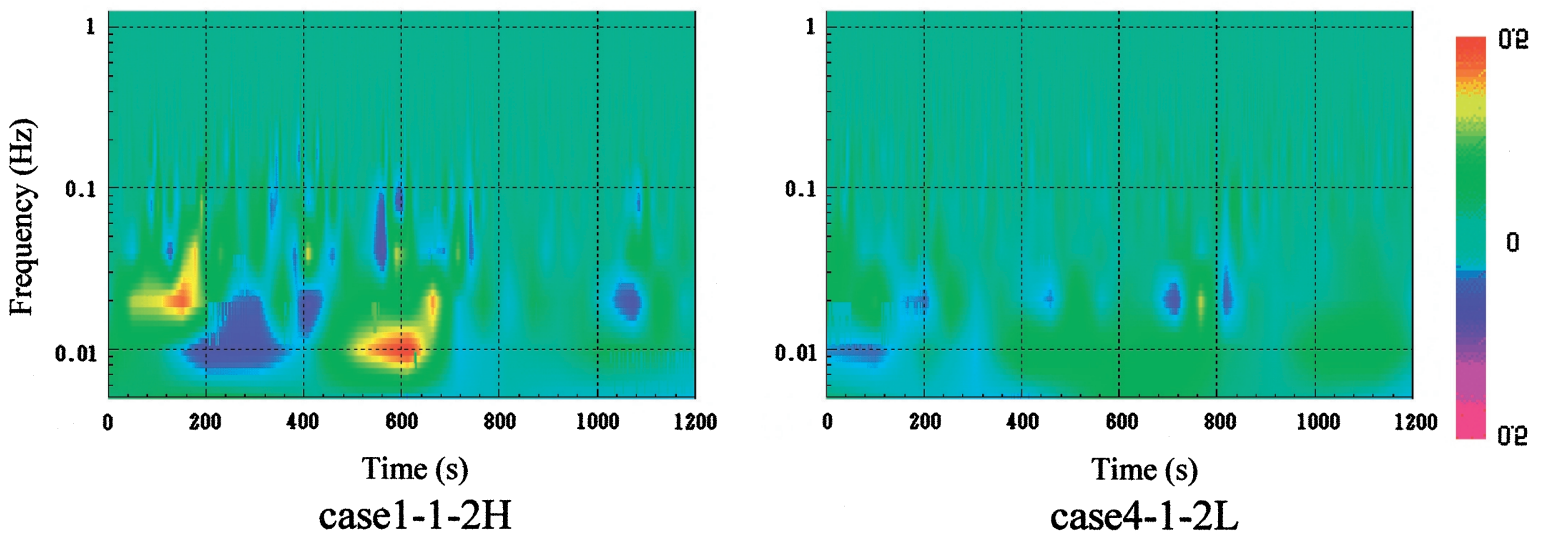

Fig. 7. Wavelet analysis in case1-1-2H and case4-1-2H.
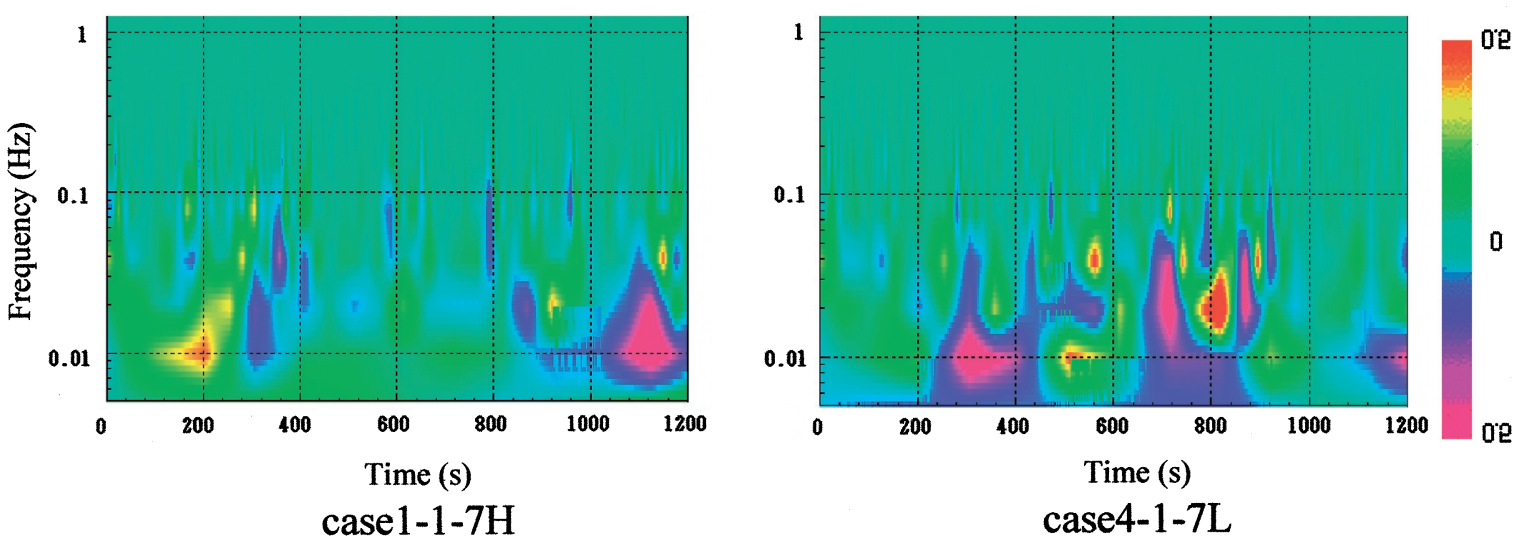

Fig. 8. Wavelet analysis in case $1-1-7 \mathrm{H}$ and case4-1-7H. 
tive cell was formed. From Fig. 5, the time scale of convection tended to become small when the coverage was large.

Figure 6 shows the results of wavelet analysis in case1-1-3H and case1-1-3L. We conducted discrete wavelet transform using the sixth floor Daubechies Mother-wavelet as analyzing wavelet. A wavelet coefficient is expressed formula below.

$$
\omega_{k}^{(j)}=2^{-j / 2} \int_{-\infty}^{\infty} f(t) \overline{\psi\left(2^{-j} t-k\right)} d t
$$

Where $\omega$ is wavelet coefficient; $f$, data function; $\psi$, Mother-Wavelet function; $k$, shifting; $j$, level. The color display expresses the size of the wavelet coefficient at each coordinate. The vertical axis corresponds to time and the horizontal one corresponds to frequency. The advantage of a wavelet analysis is catching visually the dominant frequency at each time. So we could detect rapid water temperature changes and observe the state of water surface cooling at a certain time.

From Fig. 6, it was found that a relatively high frequency band was dominant at the initial stage of cooling, and a low frequency band was dominant as time progresses. This expresses the transition from the stage, where many small cold water masses were generated, to the stage, where the thermal convective flows were formed and developed. Moreover dominant frequency bands of upper sensors were sharper than ones of lower sensors. This reason was examined to be larger turbulence intensity at upper sensors compared to that of lower sensors. In order to consider changes by coverage on a water surface, Fig. 7 shows the results of wavelet analysis in case $1-1-2 \mathrm{H}$ and case $4-1-2 \mathrm{H}$, and Fig. 8 shows the one in case $1-1-7 \mathrm{H}$ and case $4-1-7 \mathrm{H}$. The sensor in case4-1-2H was set at covered portion, and the sensor in case4-1-7H was set at not-covered portion. From Fig. 7, the reactions were weak in the covered portions. This was examined to be small turbulence intensity at the covered portions. From Fig. 8, it was found that low frequency bands in case4-1-7H were dominant at earlier time compared to case1-1-7H.

\section{CONCLUSION}

In the present study, the behavior of cold water masses generated around a water surface was investigated experimentally to understand the characteristics of a thermal convective flow in a closed water body. Furthermore, the influence of coverage on water surface was also examined. From the results obtained, the following conclusions were drawn.

(1) The number of falling and turbulence intensity of cold water masses changed with the Rayleigh number and coverage.

(2) The time scale of convection will become large as the Rayleigh number becomes large, and it becomes small as coverage becomes small. The generating cycle of cold water masses will become short as the Rayleigh number becomes large, and there is no change about the coverage.

(3) Wavelet analysis is an effective means to understand the characteristics of cold water masses at the initial stage of natural cooling on a water surface.

\section{ACKNOWLEDGEMENTS}

The authors wish to thank Laboratory of Drainage and Water Environment, Division of Regional Environmental Science, Department of Bioproduction Environment Science, Facully of Agriculture, Kyushu University for the convenience in the conducting the experiment.

\section{REFERENCES}

Eguti, T. 1998 Vertical Thermal convective Flow Caused by Water Surface Cooling. Kyushu University graduation thesis, (in Japanese)

Masujima, H. 2001 Water Quality Purification Using aquatic plants. Collection of papers the Japanese society of irrigation, drainage and reclamation engineering, (in Japanese) 33(8): 3-7 